\title{
Interview with Hilary Putnam
}

Michela Bella, Anna Boncompagni and Hilary Putnam

\section{OpenEdition}

\section{Journals}

Electronic version

URL: http://journals.openedition.org/ejpap/357

DOI: 10.4000/ejpap.357

ISSN: 2036-4091

\section{Publisher}

Associazione Pragma

\section{Electronic reference}

Michela Bella, Anna Boncompagni and Hilary Putnam, « Interview with Hilary Putnam », European Journal of Pragmatism and American Philosophy [Online], VII-1 | 2015, Online since 07 July 2015, connection on 15 September 2020. URL : http://journals.openedition.org/ejpap/357

This text was automatically generated on 15 September 2020

Author retains copyright and grants the European Journal of Pragmatism and American Philosophy right of first publication with the work simultaneously licensed under a Creative Commons Attribution-

NonCommercial-NoDerivatives 4.0 International License. 


\title{
Interview with Hilary Putnam
}

\author{
Michela Bella, Anna Boncompagni and Hilary Putnam
}

\section{EDITOR'S NOTE}

The interviews are part of the project "Strengthening the relevance of the American Philosophy to Contemporary Philosophia in Europe and America" sponsored by the Society for the Advancement of Amercian Philosophy and University of Molise.

Michela bella \& Anna BONCOMPAGNI - This conversation will focus on your role and your position with respect to pragmatism; those who you consider allies and enemies in the field; and then finally your ideas about the future of philosophy and the future of pragmatism. You worked with famous philosophers like Carnap, Reichenbach and many others. But let us start from the beginning.

Hilary PUTNAM - My alma mater was the University of Pennsylvania. The first teacher who really influenced me there was a pragmatist. His is an interesting story. His name was C. West Churchman. (I do not know what his first name was, because he obviously did not like it.) He was a philosopher of science for a while, but then he eventually left the field of philosophy, and became Professor of Operations Research at the University of California. He was a pragmatist, and he was a student - which makes me a "grandstudent" - of a philosopher named E. A. Singer Jr., who was in turn a student of William James. Singer created a pragmatist tradition at the University of Pennsylvania. The other pragmatist at that point - she did not even have tenure, she was just an assistant professor but later she became a full professor - was Elizabeth Flower. So, there was a pragmatist tradition at the University of Pennsylvania. Singer was retired by the time I came, I never met him, but I heard about him from West Churchman, and I read one of his books, a little book called Modern Thinkers and Present Problems. I was strongly influenced by Churchman in my undergraduate years. For me, the pragmatist theory of truth is not that important (in fact, I regard it as mistaken), and I don't think Churchman mentioned the pragmatist theory of truth, nor do I remember Singer's book talking about it. But what Churchman talked about was what I call the entanglement of fact and value. I quoted in one of my books 
E. A. Singer, saying four things (which were in turn quoted by Churchman in his lectures): 1) knowledge of facts presupposes knowledge of values; 2) knowledge of values presupposes knowledge of facts; 3) knowledge of theories presupposes knowledge of facts; and 4) knowledge of facts presupposes knowledge of theories. I think by "facts" Singer probably meant observational facts, and by "theories" he meant things beyond observational facts. So, the idea of a triple entanglement of theory, value, and fact is what I got from Churchman and Singer. Unfortunately, I forgot all about it for quite a few years, and had to rediscover it for myself.

M. B. \& A. B. - This is one of the main topics of your whole work.

Hilary PUTNAM - Yes, this is also a central topic of my recent work. The other teacher at the University of Pennsylvania who was very interested in and sympathetic to pragmatism, trying to bring pragmatism, logical empiricism and perhaps a little Wittgenstein together, was Morton White. (Morton White was the professor who suggested that I go to graduate school in philosophy!) He is author of a great book titled Toward Reunion in Philosophy. He and at the same time Quine attacked the analytic/synthetic dichotomy. Quine and White were friends, but neither got the idea from the other. In fact, in a paper titled "A Philosophical letter from Alfred Tarski" (published in The Journal of Philosophy in 1987), White reports that both he and Quine were influenced by Alfred Tarski, with whom Quine discussed the dichotomy and with whom White corresponded about it. In Toward Reunion in Philosophy White makes a point which Quine unfortunately rejected. White argued rightly that if the analytic/ synthetic distinction or dichotomy is untenable, so is the fact/value dichotomy. There is an argument in Toward Reunion in Philosophy that I remember very well in which White argues that when the positivists try to explain how you recognize a factual judgment, they talk about "observation predicates," but the only way they tell you what an observation predicate is is by giving a list. So, if I say that "steal" is an observation predicate, then "he stole a purse" must be a "factual" judgment, but if I say it is a value predicate, then it must be "cognitively meaningless." This is wholly unsatisfactory. The idea that the fact/value dichotomy falls if the analytic/synthetic distinction falls, is due to Morton White. For me, the essence of pragmatism is the idea of the entanglement of fact-value-theory. And that idea you find in James, in a lot of places, and in Dewey and in all the classical pragmatists.

\section{B. \& A. B. - What about your successive steps?}

Hilary PUTNAM - I did my graduate work in three years. I spent one year at Harvard, and coincidentally Morton White left Pennsylvania and went to Harvard the same year I did. I was Morton White's teaching fellow in a course in American philosophy at Harvard in 1948-49. But Harvard, although it admitted me, did not give me money, and when I asked if I could get financial support for the next year, they said: "You have to wait to the spring and pass the preliminary examinations for the Ph.D.." I did not want to make my future dependent on that. I wrote away for a teaching fellowship. I was offered one at Penn (where I had already been) and one at UCLA. I took the one at UCLA. There was a pragmatist there too, Abraham Kaplan, who had been a student of both Dewey and Carnap. I thought that I was going to UCLA to work with Kaplan, but he did not impress me, and I ended up working with Reichenbach, who fascinated me from day one. A wonderful human being and one of the greatest teachers on the planet. 


\section{B. \& A. B. - You had conversations with him}

Hilary PUTNAM - Many times. Reichenbach was a great teacher. It was not just a natural gift, although a natural gift he certainly had, it was not just his charisma: he loved pedagogy, he loved thinking about how to teach. But he also could do it and not just think about it. He gave a course in inductive logic which had 300 students. When he died, the number went down to 30 , to 10 , and then it was discontinued! Incredibly fascinating, his course on the philosophy of space and time. He never called himself a logical positivist. He always called himself a logical empiricist, because he didn't like the term "positivist," and he had the same objection Dewey had, namely that the whole idea of sense data, that everything is a construction out of our own sense data, is wrong.

Reichenbach probably regarded "metaphysics" as a dirty word. However, unlike Carnap - who was always saying that metaphysics is nonsense - Reichenbach talked about Leibniz and Kant with considerable respect, especially referring to philosophy of space and time. Carnap is still much more highly reputed than Reichenbach by analytic philosophers, but I think Reichenbach's work deserves to last, not because his views were right, but because they can be built on. Reichenbach was interested in the metaphysical implications of these great new scientific theories like quantum mechanics and relativity theory for traditional problems about the nature of time, the nature of space, causality, and so on. At this time, for example, there are philosophers like Tim Maudlin at NYU who are continuing that very well, and I think it is something that should and will continue.

When I got my job at Princeton - I got my Ph.D. in 1951, I taught one year at Northwestern in Illinois, and then I got a job in Princeton starting in the fall of 1953, and that was where I met Carnap - I was hired as a philosopher of science: I had been trained by Reichenbach; my job at Northwestern had been in philosophy of science, and at Princeton I was also a philosopher of science. At the same time I was developing as a mathematician. I think that in my first decade I probably published more mathematical papers than philosophical papers. My first philosophical paper came from something I said in a conversation with Carnap, who told me "you have to published that." It was "Synonymity, and the Analysis of Belief Sentences," in the journal Analysis. And then I published a couple of papers on the incompatibility of red and green, which is something that phenomenologists used as an example of a synthetic a priori truth. I wrote opposing that view. But at the same time I was developing as a mathematical logician. Probably, it was the importance of my work as a mathematical logician that got me tenured in Princeton. Before 1957 I was already publishing significant results in mathematical logic. Then in the fall of 1957 I finally got my first semester of leave. I had been teaching over six years without any leave at all. I got a one semester fellowship at Herbert Feigl's Center for the Philosophy of Science at the University of Minnesota, which was wonderful. (Feigl was an old friend of both Carnap and Reichenbach.) A whole semester of leave! By that time, by 1957, I was finding things I wanted to say in philosophy, and that's when I wrote "The Analytic and the Synthetic." A lot of my later philosophy is already in "The Analytic and the Synthetic": the idea of externalist semantics (although I did not realize it at that time), the idea that reference is preserved across theory change, contrary to Carnap's view, and therefore also preserved across changes in method of verification, the idea of law-cluster concepts - they are all in that paper. 
M. B. \& A. B. - You were talking about metaphysics.

Hilary PUTNAM - At that point, I had not yet started thinking about ethics. I think that for a while I did believe in the fact/value dichotomy: I had fallen under the influence of Reichenbach and Carnap. (Reichenbach's "voluntarism" is like R. M. Hare's "universal prescriptivism": it is a sort of non-cognitivism with Kantian elements.) The problems I wanted to think about at the start of my teaching were the nature of mathematical truths and the existence of mathematical objects. But "The Analytic and the Synthetic" came to be written because I quickly discovered that Feigl, Wilfrid Sellars, and other people at the Center for the Philosophy of Science in Minnesota were all convinced that the analytic/synthetic distinction was wholly unproblematic, and that Quine must be crazy. What I did in "The Analytic and the Synthetic" was use the philosophy of physics that I learned from Reichenbach, but use it to undermine the analytic-synthetic distinction that neither Carnap nor Feigl nor Sellars questioned. If my analysis of the history of physics is right, then the analytic-synthetic distinction can't be right, I argued. I really think that "The Analytic and the Synthetic" is the paper in which I found my philosophical voice. I went on, between 1957 and 1960, to formulate "functionalism" in the philosophy of mind. Thinking about the fact/value dichotomy was the result of the impact of Paul Ziff. Ziff wrote a book called Semantic Analysis, which he read in draft at a seminar in Princeton in the late 1950s. He had a very important impact on me, because the last chapter of Semantic Analysis is on the fact/value dichotomy, and Ziff argued that it has no linguistic basis whatsoever! That shocked me because one of my three major subjects in college was linguistics. Noam Chomsky and I were almost the only undergraduates studying linguistics at Penn. So, once Ziff confronted us with the idea of bringing linguistics to bear on the so called fact/value dichotomy (which was claimed to be an analysis of the meaning of ethical terms), and showed that from a linguistic point of view it is a ridiculous analysis. I was deeply impressed. A few years later, I left Princeton because I had an invitation to create my own philosophy department at MIT. I went in MIT in 1961, and in 1965 I moved to Harvard. But in four years I created the whole MIT philosophy department. I gave one seminar on the fact/value dichotomy during my MIT years in which I went over the questions that Ziff had raised. We used Ziff's book, and I came to the conclusion that from a linguistic point of view one must not pretend that any version of emotivism/voluntarism/prescriptivism is an analysis of what ethical sentences mean, because it just isn't right. They are not simply expression of emotions. That was the beginning of my shift away from the noncognitivism I had picked up from Carnap and Reichenbach. I don't know when I wrote "Literature, Science, and Reflection" (it was published in 1978), but that is my first article broadly on ethics, and also arguing for the cognitive value of art and literature.

M. B. \& A. B. - You mentioned your first encounter with pragmatism when you were undergraduate. But in which way was pragmatism usually perceived?

Hilary PUTNAM - I do not think West Churchman used this word at all. I knew that he was Singerian, and that Singer was a student of James, but I did not think myself as belonging to a movement or sect called "pragmatism." Churchman actually informed his attack on the fact/value dichotomy with a deep knowledge of experimental design. Even great philosophers of science like Carnap and Reichenbach never mentioned modern statistics or modern experimental design. You cannot even find the key concept of "likelihood" in the index of Carnap's great book on inductive logic, 
nor you find it in the index of Reichenbach's Theory of Probability. They acted as if the whole subject of empirical inference didn't exist, as if nothing happened after Mill except themselves. But, because Churchman had been doing experimental design during the war, he knew first hand a lot about experimental design. And his major argument was that in designing an experiment a judgment of value is always involved, you cannot minimize all the different types of risk. There are two basic types of risk, (I) the risk of false positives and (II) the risk of false negative. You cannot minimize both types of risk at once. There is a famous paper about this written by one of Churchman's students, Richard Rudner. From the very beginning, even in the simplest cases, the decision depends on what risk levels are acceptable, and this is a value judgment. This is really one of Churchman's and Rudner's lasting original contributions to the discussion of the fact/value dichotomy, and it is still neglected.

M. B. \& A. B. - Could you please tell us something more about the steps you took toward pragmatism.

Hilary PUTNAM - My wife, Ruth Anna Putnam, had a big influence. She was really much more a Dewey scholar than I. The enthusiasm for James is something that I got from Jacques Barzun's book A Stroll with William James. Rorty wrote a very positive review of that book, and when I read it I got a tremendous interest in William James. And later Ruth Anna got me interested in reading Dewey. I did have one seminar on Dewey in graduate school with Donald Piatt who was student of Dewey's. In fact Piatt has an article in the Dewey volume of the Library of Living Philosophers. But Piatt had an interpretation of Dewey's ethical theory that I think is too relativist. About the idea of problem solving Piatt took a more relativist approach than I think Dewey would have. Dewey certainly respected him, he regarded him as an important student. It was with Piatt that I had read Logic: The Theory of Inquiry, which I am very grateful for, since that is a hard book, and I do not think I would have worked through it on my own without a first rate teacher. But when I came back to pragmatism around 1990, I had not done anything with pragmatism for a long time, and I thought about the fact/value dichotomy in the 1960s more as a result of Ziff's book, as I described a few minutes ago. I had no positive views about ethical theory at that time (the 1960s), but that suspicion of the whole idea of a "fact/value dichotomy" had already been planted. But it was a number of years before that issue moved to the center of my attention. I think it was really as a result of my friendship with two economists, Amartya Sen and Vivian Walsh, that I came to realize that the fact/value dichotomy had an enormous negative influence on modern economics. That was when I learned, for example, that during the Great Depression Lionel Robins - later Sir Lionel Robins, and still later Lord Lionel Robins, basically the great man at the London School of Economics - was saying "well, you can't say that there ought or ought not to be welfare because judgments of value are meaningless, you can argue about judgments of value." I came to realize that the positivist fact/value dichotomy was having an enormous real world impact of a very bad kind. So, when I came to realize that that issue was not a purely theoretical one, and that non-cognitivism about values really corrupts economics, the first thing I did was to try to find a more sound philosophy of language basis for what my friend Amartya Sen was doing. That led to my book The Collapse of the Fact/Value Dichotomy, part of which was an explicit discussion of Sen's work. 
M. B. \& A. B. - You said you are not a pragmatist as you are not a Wittgensteinian. You do not carry a membership card. But which traditions or thinkers do you feel closer to you?

Hilary PUTNAM - If I used any of these terms - this is something suggested by Mario De Caro - I would call myself a liberal naturalist. I am a pragmatist in the sense that I am a liberal naturalist. And I think that Wittgenstein can also be put under the umbrella of liberal naturalism.

M. B. \& A. B. - Which are the topics on which you feel more in the same way as pragmatism?

Hilary PUTNAM - Three topics. My wife and I worked together, especially on the connections between Dewey's ethics, his view of scientific method, and his philosophy of education: our papers on pragmatism will be published by Harvard in 2016. But Rorty also influenced me - to combat Rorty. We were not enemies, we loved each other, but we differed very much, and differences were stimulating. I think I clarified my own positions in my head by seeing where I disagreed with Rorty.

M. B. \& A. B. - You and Rorty have contrasting but also complementary positions. For instance when he tries to read James and Dewey as anti-realists, and you say "No!"

Hilary PUTNAM - Fidelity to texts was not one of Dick Rorty's strengths.

M. B. \& A. B. - It is interesting to have these different ways of approaching pragmatism. Which are the themes of pragmatism towards which you feel more distant?

Hilary PUTNAM - Let me think a moment. On the positive side, where I feel closer to pragmatism: besides the threefold entanglement, I also feel the emphasis on education. The idea that really philosophy should begin in childhood. Where I feel more distant it is not pragmatism as such. It is very hard to say. I have not done anything really with Mead, partly because Mead did not write a book. I have done a lot with Peirce, and James, and Dewey. Apart from a nominal agreement on a theory of truth - Peirce criticizes James' interpretation, he tells us "I am not a pragmatist, I am a pragmaticist"- the pragmatists differed so much from each other. And you have Schiller's version! That's the one closest to Rorty. I have differences with each of them. I guess with James it is mainly the theory of truth that I disagree with. But a great deal of what he said does not depend on his theory of truth, so I am very often in sympathy with him. With Dewey: Ruth Anna and I actually have a paper on Dewey's Logic. Dewey hits maybe a little too hard on the idea that science should have practical pay-off. The weakness in his Logic is perhaps there. I think it is a great book, but the title Logic was unfortunate because "logic" had come to mean something different. It is really logic in the sense of Mill's Logic. In fact, I see Dewey's Logic as a reply to Mill's Logic. Mill was saying "the way to make social science progress is reductionism." Social sciences will only progress when they reduce sociology to perfected individual psychology. And Dewey said no: the way to improve sociology is to do sociology! Pragmatists had an enormous respect for Mill. James dedicated Pragmatism to Mill, but I think their anti-reductionism is enormously important. The philosophy of mathematics is something that I do not really like at all in either James or Dewey. I do not think they knew mathematics, and I think in many ways their philosophy is 19th century. There is very little advance in the positive philosophy of mathematics beyond Mill's views in either Dewey or James. Unlike Peirce they were not mathematicians. 
M. B. \& A. B. - There is a letter in which Peirce tells James "You have to study mathematics."

Hilary PUTNAM - Mill's was the most impressive attempt to defend the empiricist idea that mathematical knowledge is empirical. I do not think he is right, but he was a genius who at least could make a case for that. There is an interesting comparison to be drawn, and to be reflected on, between Frege and Peirce. Because Frege - he is not the first in this, there is already Bolzano, there is already 19th century mathematics is trying to show that contrary to Kant, pure mathematics does not presuppose spatial or temporal intuition. And Peirce was trying to say "no, pure mathematics is geometry, logic itself is geometry, logic itself is diagrams." I think that difference is neglected. There is room for more than one good Ph.D. thesis on that!

M. B. \& A. B. - What do you perceive is your own contribution to the pragmatist tradition?

Hilary PUTNAM - That's for other people to say! I do think that Rorty and Brandom are terribly careless readers. When Rorty says that Dewey doesn't think that ethics can be scientific, I can point to pages in the Logic where he said absolutely the reverse. I do not like what I call text free interpretation. I tried to say: "Look, if you are going to write about the classical pragmatists, let's first get clear what they actually said. They are not just something to use!"

My diagnosis of Rorty is that the Carnapian fact/value dichotomy is deep in Rorty's soul. Carnapian hatred for metaphysics is deep in Rorty's soul. What Rorty wanted to do is to go beyond Carnap: well, if metaphysics is no good, then what is the business of privileging science? Why should we say that the aim of language is to make correct predictions? Why shouldn't I say that the aim of language is to cope? And at the very end of his life, he did not have time to work that out, Brandom had convinced him that you shouldn't talk about the aim of language at all. At the very end Rorty said, "Well, it was a mistake for me to think that the aim of language is to cope, there is no aim of language outside of language." But it is not clear where that was going to go.

M. B. \& A. B. - How was your relation with Rorty?

Hilary PUTNAM - We were dear friends.

M. B. \& A. B. - What is your opinion on his work?

Hilary PUTNAM - He certainly gets people reading in pragmatism. That is certainly true of him. As I said, my reading of James was inspired by Rorty's review of Barzun. And I Think Rorty's Philosophy and the Mirror of Nature - I disagree with it - but is certainly a first rate book.

M. B. \& A. B. - Regarding other kinds of pragmatism and neo-pragmatism, what do you think about what is growing in Europe and in England, what they call the British pragmatism?

Hilary PUTNAM - I have seen a little of Huw Price's work, but I cannot really judge it. It seems to me anti-realist in spirit, and, I am maybe wrong, my impression is that it is a version of anti-realism. I certainly see Brandom as in many ways close to Quine.

M. B. \& A. B. - We did not talk much about Quine. What was your relationship with him, and what is your idea of his philosophy?

Hilary PUTNAM - Quine is certainly one of the great philosophers of my lifetime. Politically we weren't close at all. He was much closer to Bob Nozick. Humanly, he was a lovely person. He was very old-fashioned in a good sense. For example, if you 
invited Quine to dinner, he would never talk about himself, he would talk about something which interested the person he was talking to. Lovely manners. He was born in 1908: I would say that he was a man of the Belle Epoque. And he is a wonderful writer, a wonderful stylist. Both Quine and Goodman were good friends of mine. Goodman I think was closer to pragmatism because Goodman wants to give equal emphasis to the arts as to science, and there is no fact/value dichotomy in Goodman.

M. B. \& A. B. - You wrote a book on Jewish tradition, and you are Jewish. Also Bernstein is Jewish. Is there any link or closeness between Jewish culture and pragmatism?

Hilary PUTNAM - I do not see any direct connection. Any religious tradition is like an ocean. I was in the Committee on the Study of Religion at Harvard. It is like a department as it gives undergraduate degrees and Ph.Ds. The great founder of that Committee was Wilfred Cantwell Smith. He once said: "I could show as much diversity among Methodist communities in London in 1815 as it is supposed to exist among the world religions." He distinguished between traditions - Judaism is a tradition, Christianity is a tradition - and within traditions he said that there are communities of faith. He felt that analytically the concept of religion was a bad notion. There are endlessly many communities of faith within each of the major traditions. Judaism is my tradition, but I interpret it in my own way. When my friend, a wonderful critical philosopher, Sidney Morgenbesser, died, Leon Wieseltier, one of the speakers at his memorial, said that "Sidney proved that one can be rooted in a tradition without being a plant." I think that is what I want: I want to be rooted in a tradition without being a plant!

M. B. \& A. B. - One last question. What do you think about the future of pragmatism? Does pragmatism have something to say? 